\title{
Nanoparticles Biosynthesized by Yeast: A Review of their application
}

\section{Biosyntéza nanočástic kvasinkami: review jejich aplikace}

\author{
Sylvie SKALICKOVA, Mojmir BARON, Jiri SOCHOR \\ Department of Viticulture and Enology, Faculty of Horticulture, Mendel University in Brno, Valtická 337, CZ-691 44 Lednice, \\ Czech Republic \\ e-mail: sylvie.skalickova@gmail.com
}

Reviewed paper / Recenzovaný článek

Skalickova, S., Baron, M., Sochor, J., 2017: Nanoparticles Biosynthesized by Yeast: A Review of their application. Kvasny Prum. 63(6): 290-292

The green biosynthesis of nanoparticles is one of the most discussed topic of current nanotechnology. It has been estimated the plants, bacteria, yeasts or some lower organism could synthesize nanoparticles such as quantum dots, organic and inorganic based nanoparticles. Yeasts are eukaryotic microorganisms and generally, several strains play an important role in food industry due their ability to sugar fermentation. A novel approach of their use could be a production of metal nanoparticles and nanostructures via their reducing enzymes intracellularly or extracellularly. The focus of this review is the application of yeast in the green synthesis of inorganic nanoparticles and the innovation use in the fermentation industry.

Skalickova, S., Baron, M., Sochor, J., 2017: Biosyntéza nanočástic kvasinkami: review jejich aplikace. Kvasny Prum. 63(6): 290-292

$\checkmark$ současnosti je v oboru nanotechnologie jedním z velmi diskutovaných témat zelená syntéza nanočástic. Ta byla prokázána u rostlin, bakterií, kvasinek a některých nižších organismů, které mohou syntetizovat nanočástice jako jsou například kvantové tečky, organické či anorganické nanočástice. Kvasinky jsou eukaryotické mikroorganismy, z nichž řada je využívána v potravinářském průmyslu díky schopnosti zkvašovat cukry. Nový prístup v použití kvasinek představuje intracelulární a extracelulární produkce kovových nanočástic a nanostruktur skrze enzymatickou redukci. Review se zaměřuje na aplikaci kvasinek pro zelenou syntézu anorganických nanočástic pro inovaci v kvasném průmyslu.

Skalickova, S., Baron, M., Sochor, J., 2017: Biosynthese von Nanopartikeln durch die Hefe: Review ihrer Applikation. Kvasny Prum. 63(6): 290-292

Im Gegenwart gibt im Bereich Nanotechnologie als eine sehr diskutierte Thema die grüne Synthese von Nanopartikeln (bzw. Nanoteilchen). Diese Synthese wurde bei den Pflanzen, Bakterien, Hefen und einigen niedrigeren Organismen nachgewiesen, die die Nanopartikel z.B. Quantenpunkte, organische oder anorganische Nanoteilchen synthetisieren können. Die Hefezellen stellen eine eukaryotische Mikroorganismen dar, einigen von denen, Dank der Fähigkeit die Sachariden zu vergären, werden in der Lebensmittelindustrie angewandt. Der neue Zutritt in dem Hefeanwendungsbereich stellt die Intrazellulare- und Extrazellulare Metallnanoteilchenproduktion und Nanostruktur unter Anwendung der enzymatischen Reduktion dar. Review wird fokussiert auf die Hefeapplikation der grünen Synthese von anorganischen Nanoteilchen für die Innovation in der Gärindustrie.

Keywords: green biosynthesis, nanoparticles, yeast, non-toxicity Klíčová slova: zelená biosyntéza, nanočástice, kvasinky, netoxičnost

\section{INTRODUCTION}

Over the course of human history, and using a system of trial, error, and careful observation, different cultures began producing fermented products such as beer, wine, sauerkraut, soya sauce, acetic acid and others. Many years later, understanding of the fermentation process comes from the work of the French chemist Louis Pasteur who firstly demonstrate that fermented beverages result from the action of living yeast transforming glucose into ethanol. Moreover, Pasteur demonstrated that microorganisms are capable to convert sugars into alcohol from grape juice, and that the process occurs in the absence of oxygen (Gal, 2008; Walker, 1958).

This eukaryotic microorganism called yeasts are classified in the kingdom Fungi, with about 1,500 species currently described. Yeasts according to the invention are classified in phylum Ascomycota, in subphylum Saccharomycotina, in the class Saccharomycetes, in the order Saccharomycetales, in the family Saccharomycetaceae, and in the genus Yeasts (Lachance, 2016).

With the mass production of fermented products, the requirements on sterile environment have been occurred and the protection against pathogenic microorganisms (Junker et al., 2006; Zhao et al., 2015).

In the field of pathogenetic microorganism inhibition, the metal nanoparticles are investigated as a promising and low-cost antimicrobial agent. Generally, selenium nanoparticles, silver nanoparticles have to be considered as a substitution agents of antibiotics. Nowadays, the nanoparticles seem to be novel approach in the field of fermentation industry (Kuang et al., 2016; Lin et al., 2016; Paiano et al., 2016). The main advantage are the unique properties of na- noscaled particles which provide a strong beneficial effect over many applications (Chaudhuri and Paria, 2012; Katz and Willner, 2004; Tang and Kotov, 2005).

The aim of this review is to summarize the use of biosynthesized nanoparticles by yeast in the fermentation processes and put the general overview to given problematics.

\section{NANOPARTICLE GREEN BIOSYNTHESIS}

In the contrary of physical or chemical route of metal nanoparticle synthesis, the biosynthesis is eco-friendly approach based on reactants utilization by metabolism of organisms (Iravani, 2011). Generally, the principle of biosynthesis lies in adding the source of the element to the medium in an amount of about $1 \mathrm{ppm}$ to about 1,000 ppm. Generally, the source of the element should not be present in an amount that is too toxic for the yeast. The biosynthesis could be initiated by several metabolites such as carbonyl groups, terpenoids, phenols, amines, amides, proteins, alkaloids or other reduction substances presented on the used organism (Kouzegaran and Farhadi, 2017; Duan et al., 2015).

Yeast production is easy controlled in laboratory conditions, the rapid grow of yeast strains and the use of simple nutrients possess several benefits in the mass production of metal nanoparticles. For this purpose, the yeast strains Candida glabrata and Saccharomyces Pombe have been described for the production of intracellular synthetized cadmium sulfide, silver, selenium, titanium and gold nanoparticles (Moghaddam et al., 2015; Feng et al., 2017). Moreover, the extracellular synthesis has been investigated in the case of silver and cadmium sulfide NPs (Eugenio et al., 2016; Kowshik et al., 2003).

The most abundant principle of nanoparticle production by yeast could be explained by the presence of membrane bound (cytosolic) oxidoreductases and quinones. It was mentioned the $\mathrm{pH}$ sensitive 
oxidoreductases could work in alternative manner depends on the value of $\mathrm{pH}$. The increased $\mathrm{pH}$ in the internal environment of yeast could cause activization of reductases with could reduce the metal ions with the simultaneous nanoparticles formation (Salunke et al., 2015) as is shown in Fig. 1. In addition, the generation of stress response on the presence of metals in the nutrient medium could initialize metabolic cascade of reactions leads to production of phytochelatin synthase and glutathione which are responsible for internal stress elimination (Kowshik et al., 2003). Both compounds show unique redox and nucleophilic properties lead to bioreduction of metal ions employed to the nanoparticle formation due to its ability to bind ions of cadmium, zinc, silver, selenium, gold, nickel, copper and other metals (Zhang et al., 2016). It follows from these mechanisms that the main goal of the nanoparticle biosynthesis is elimination of nanoparticle toxicity via cellular mechanisms and in such cases the biofilm formation on the surface of nanoparticles (Eugenio et al. 2016). However, there is no evidence showing that yeast uses biosynthetic nanoparticles for their metabolism.

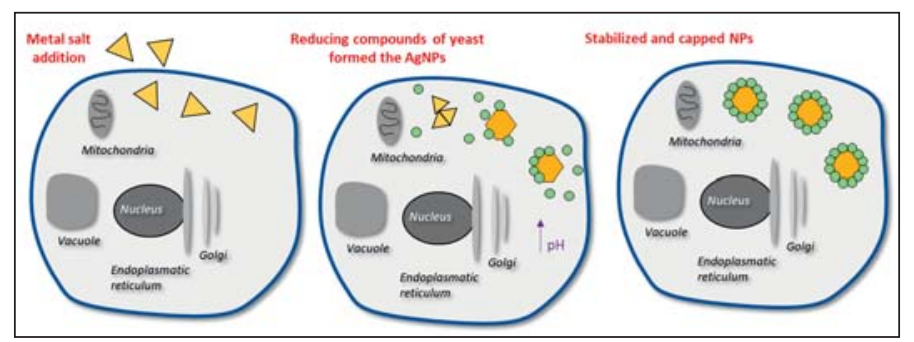

Fig. 1 Scheme of the green biosynthesis of metal nanoparticle in yeast. The metal salt is absorbed via cell wall and plasmatic membrane. The $\mathrm{pH}$ increase is occurred in the internal environment and the natural reducing agent capped the forming nanoparticles.

\section{APPLICATION OF BIOSYNTHESIZED NANOPARTICLES BY YEAST}

Metal nanoparticles are utilized in several fields of application such as drug delivery, in-vivo imaging, biosensors, antimicrobial, antifungal and anticancer properties (Moghaddam et al., 2015; Eugenio et al., 2016; Roy et al., 2015). Herein we described two main ways of NPs application.

\subsection{Extracted NPs}

Nanoparticles produced intracellularly or extracellularly should be purified from the yeast strain. Extracellularly produced nanoparticles are easily extracted by centrifugation or dialysis from media. Yeast strains which produce nanoparticles intracellularly should be carefully lyzed chemically or physically (Besner et al., 2008). Risk of nanoparticle degradation or aggregation could occure in dependence of used technique and finally, the nanoparticle yield is not too high Several authors described extraction protocols which enable to production pure and highly effective nanoparticles regarding to conservation of nanoparticles properties. The main advantage is the presence of different functional groups conjugated with the surface of biosynthesized nanoparticles which play an important role in various applications (Sowani et al., 2016).

The use of biosynthesized nanoparticles is based on their properties such as antimicrobial, antiviral, anticancer activity (Li et al., 2015; Sharma et al., 2016; Rai et al., 2016). The mechanism of action could be explained by the ability of produce reactive oxygen species, damage the bacterial cell wall, blocking pathogen's metabolism or they are able to cause inflammation or both. Thus, it is a less toxic variant having comparable effects to the chemically synthetized nanoparticles which possibilities of application is well summarized / Mandal et al., 2006).

\subsection{Application of yeast producing metal nanoparticles}

In this approach, the extracellularly production of nanoparticles could be advantageous in the fermentation industry. Fermentation processes could be in jeopardy by contaminating bacterial strains ( $\mathrm{Li}$ et al., 2014). Yeast strains which are used in fermentation processes could produce nanoparticles as an own effective defense against pathogenic microorganism which prevents the fermentation process (Moghaddam et al., 2015). Although, the relevant data is not known from the literature, the effects of various types have been described in the connection of used the metal nanoparticles. Highly discussed is silver nanoparticles which show a broad spectrum of antibacterial activity and are not toxic for higher organisms.

The perspectives of this approach are highlighted in the two patents. Application of silver nanoparticles in controlling major contaminating bacteria in fuel ethanol fermentation production process is based on $S$. Cerevisiae biosynthesis of silver nanoparticles which control a major contaminating bacteria in a fuel ethanol fermentation production process. The described mechanism of action is the inhibition of Lactobacillus fermentum, Lactobacillus brevis and Pediococcus pentosaceus (Goodle Patents, 2015). The production of sulfurfree nanoparticles by Saccharomyces cerevisiae have been patented. This yeast producing selenium nanoparticles could be employed in applying selenium for the glass and animal feed solar cell, glass, printable electronics medical and fermentation fields industries due to the selenium properties (Mester, Z. and Ouerdane, L., 2015).

\section{CONCLUSIONS}

In contrary of medicinal or technical use of nanoparticles, the nanotechnology in fermentation industry is in the beginning of the research. It clearly follows, there is a plenty of space to nanotechnology principles application. We can conclude a big advantage in this field is the knowledges in other disciplines which could be easily transferred. Although, the usability of nanoparticle producing yeast strains is not fully examined, their potential in the fermentation industry is highly needed.

\section{ACKNOWLEDGMENTS}

This work was supported by the Applied Research and Development of the National and Cultural Identity, project DG16P02R017 "Vinohradnictví a vinařství pro zachování a obnovu kulturní identity vinařských regionů na Moravě“.

\section{REFERENCES}

Besner, S., et al., 2008: Ultrafast laser based "green" synthesis of non-toxic nanoparticles in aqueous solutions. Applied Physics aMaterials Science \& Processing, 93(4): 955-959.

Chaudhuri, R. G., Paria, S., 2012: Core/Shell Nanoparticles: Classes, Properties, Synthesis Mechanisms, Characterization, and Applications. Chemical Reviews, 112(4): 2373-2433.

Duan, H. H., Wang, D. S., Li, Y. D., 2015: Green chemistry for nanoparticle synthesis. Chemical Society Reviews, 44(16): 5778-5792.

Eugenio, M., et al., 2016: Yeast-derived biosynthesis of silver/silver chloride nanoparticles and their antiproliferative activity against bacteria. Rsc Advances, 6(12): 9893-9904.

Feng, H., et al., 2017: Green Biosynthesis of CdS Nanoparticles Using Yeast Cells for Fluorescence Detection of Nucleic Acids and Electrochemical Detection of Hydrogen Peroxide. International Journal of Electrochemical Science, 12(1): 618-628.

Gal, J., 2008: The discovery of biological enantioselectivity: Louis Pasteur and the fermentation of tartaric acid, 1857 - A review and analysis $150 \mathrm{yr}$ later. Chirality, 2008. 20(1): 5-19.

Google Patents, 2015: Application of silver nanoparticles in controlling major contaminating bacteria in fuel ethanol fermentation production process.

Iravani, S., 2011: Green synthesis of metal nanoparticles using plants. Green Chemistry,13(10): 2638-2650.

Junker, B., et al., 2006: A next generation, pilot-scale continuous sterilization system for fermentation media. Bioprocess and Biosystems Engineering, 28(6): 351-378.

Katz, E. , Willner, I., 2004: Integrated nanoparticle-biomolecule hybrid systems: Synthesis, properties, and applications. Angewandte Chemie-International Edition, 43(45): 6042-6108.

Kouzegaran, V. J., Farhadi, K., 2017: Green synthesis of Sulphur Nanoparticles assisted by a herbal surfactant in aqueous solutions. Micro \& Nano Letters, 12(5): 329-334.

Kowshik, M., et al., 2003: Extracellular synthesis of silver nanoparticles by a silver-tolerant yeast strain MKY3. Nanotechnology, 14(1): 95-100.

Kuang, H. J., Yand, L., Shah, N. P., Aguilar, Z. P., Wang, L., 2016: Synergistic in vitro and in vivo antimicrobial effect of a mixture of $\mathrm{ZnO}$ nanoparticles and Lactobacillus fermentation liquor. Applied Microbiology and Biotechnology, 100: 3757-3766. 
Lachance, M.A., 2016: Paraphyly and (yeast) classification. International Journal of Systematic and Evolutionary Microbiology, 66: 4924-4929.

Li, H. H., et al., 2015: Enhancing the antimicrobial activity of natural extraction using the synthetic ultrasmall metal nanoparticles. Scientific Reports, 5.

Li, K., et al., 2014: Spoilage and Pathogenic Bacteria Associated with Spoilage Process of Sichuan Pickle during the Spontaneous Fermentation. Food Science and Technology Research, 20(4): 899-904.

Lin, L., Cheng, J., Ding, L., Song W., Liu, M., Zhou, J., Cen, K., 2016 : Enhanced dark hydrogen fermentation by addition of ferric oxide nanoparticles using Enterobacter aerogenes. Bioresource Technology, 207: 213-219.

Mandal, D., Bolander, M. E., Mukhopadhyay, D., Sarkar, G., Mukherjee, P., 2006: The use of microorganisms for the formation of metal nanoparticles and their application. Applied Microbiology and Biotechnology, 69(5): 485-492.

Mester, Z., Ouerdane, L., 2015: Producing sulfur-free nanoparticles comprises growing yeast in a growth medium containing a source of an element in a bio-reducible oxidation state, Nat Res Council Canada (Cana-C) Nat Res Council Canada (Cana-C) Nat Res Council Canada (Cana-C).

Moghaddam, A. B., et al., 2015: Nanoparticles Biosynthesized by Fungi and Yeast: A Review of Their Preparation, Properties, and Medical Applications. Molecules, 20(9): 16540-16565.

Paiano, P., et al., 2016: Effect of magnetite nanoparticles on organic substrate fermentation by mixed microbial cultures. New Biotechnology, 33: S150-S150.

Rai, M., et al., 2016: Metal nanoparticles: The protective nanoshield against virus infection. Critical Reviews in Microbiology, 42(1): 46-56.
Roy, K., Sarkar, C. K., Ghosh, C. K., 2015: Photocatalytic activity of biogenic silver nanoparticles synthesized using yeast (Saccharomyces cerevisiae) extract. Applied Nanoscience, 5(8): 953-959.

Salunke, B. K., Sawant, S. S., Lee, S. I., Kim, B. S., 2015: Comparative study of $\mathrm{MnO}_{2}$ nanoparticle synthesis by marine bacterium Saccharophagus degradans and yeast Saccharomyces cerevisiae. Applied Microbiology and Biotechnology, 99(13): 5419-5427.

Sharma, H., et al., 2016: Development and characterization of metal oxide nanoparticles for the delivery of anticancer drug. Artificial Cells Nanomedicine and Biotechnology, 44(2): 672-679.

Sowani, H., et al., 2016: Green synthesis of gold and silver nanoparticles by an actinomycete Gordonia amicalis HS-11: Mechanistic aspects and biological application. Process Biochemistry, 51(3): 374-383.

Tang, Z. Y., Kotov, N. A., 2005: One-dimensional assemblies of nanoparticles: Preparation, properties, and promise. Advanced Materials, 17(8): 951-962.

Walker, T. K., 1958: Pasteur work on fermentation and its significance for present-day studies in biochemistry. Nature, 191(4614): 940-942.

Zhang, X. W., et al., 2016: Biogenic synthesis of gold nanoparticles by yeast Magnusiomyces ingens LH-F1 for catalytic reduction of nitrophenols. Colloids and Surfaces a-Physicochemical and Engineering Aspects, 2016. 497: p. 280-285.

Zhao, Z. M., Wang, L., Chen, H. Z.: A novel steam explosion sterilization improving solid-state fermentation performance. Bioresource Technology, 192: 547-555.

Do redakce došlo / Manuscript received: 06/08/2017 Prijato k publikování / Accepted for publication: 13/10/2017 